\title{
Are we »Christians« only on Sunday? What about Monday? \\ The biblical drama in four acts as a framework for an integrated view of work
}

By percentage Croatia is a highly "Christian " country (more than 91 percent), sadly that does not mean that it is a country of high ethics. In reality Croatia struggles on many ethical battlegrounds. We start this paper with the assumption that a rightly understood and clearly communicated integration of biblical faith and work can contribute to the solution of problems in Croatia. But we found through research that few people read and understand the Bible. When the Holy Scriptures do not have such importance, for most people who describe themselves as Christians, it is hard to understand and talk about the biblical view of work or biblical theology of work. We propose a new framework for an integrated view of work as a lens through which we can better understand the whole biblical story. Without looking at this more complete framework, we lose the context and conception of work.

Key words: integration of faith and work, theology of work, business ethics, corruption, ethical culture in Croatia, Bible reading habits, biblical drama in four acts, Kingdom work.

\footnotetext{
* Dražen Glavaš, DMin, teaches Business Ethics and Leadership at the University of Applied Science Vern and works as a business trainer and executive coach with ET!K. This paper is based on the author's research done for a doctoral thesis: $» C h r i s t i a n$ on Sunday and Atheist on Monday. Bridging the Faith and Work Gap in Croatian Culture«, DMin diss., Gordon-Conwell Theological Seminary, 2016; Address: S. Vojnovića 42, Gajec, HR-10000 Zagreb, Croatia.
} 
»The message of the Bible can be understood only as it is perceived from a specific cultural standpoint. God's Word is always incarnated, and different parts of the church may incarnate it differently. In other words, the content of the gospel cannot be separated from its cultural form. ${ }^{1}$

\section{Introduction}

The last census from 2011 shows that in Croatia 91.36 percent claim to be Christians, of which Roman Catholics make 86.28 percent, Orthodox 4.44 percent, Protestants 0.34 percent, and other non-denominational Christians 0.30 percent. ${ }^{2}$ By percentage Croatia is a highly »Christian« country (more than 91 percent), sadly that does not mean that it is a country of high ethics. In reality Croatia struggles on many ethical battlegrounds. The Transparency International Corruption Index ranked Croatia, in 2016, as the sixth most corrupt EU country. ${ }^{3}$ We see a gap between a declared Christian faith and the lack of visible works which should flow out from such a belief. But if faith is engrained in the Croatian culture why is it now limited to a private, Sunday only, influence? If Croatians (who call themselves Christians, meaning those who are followers of Christ) connected Sunday and Monday, living out their (spiritual, moral, ethical) values, a workplace theology that is communicated through their work, would this contribute to a positive (ethical) change in a culture? Could the integration of faith and work redeem and transform the motivation and meaning of work? In this paper we will focus on understanding the biblical framework for the integration of faith and work. We will start this paper with the assumption that a rightly understood and clearly communicated integration of biblical faith and work can contribute to the solution of problems in Croatia.

\section{(Re) Defining the Terminology}

It is important to define the language that we use, especially in religious terminology. Therefore, we should start by defining the terms that we so often use. Words like Christ, Christian and Christianity seem to be so obvious to most of the people, but are they? Many people confuse the title Christ as Jesus' last name and do not know that Christ is a title meaning »Jesus is the Messiah, the Anointed one«. The word »Christian« is mentioned only three times in the

\footnotetext{
${ }^{1}$ Bernard T. ADENEY, Strange Virtues. Ethics in a Multicultural World, Downers Grove, IL: IVP, 1995, 102.

${ }^{2}$ All the statistical information about the census are taken from Croatian Bureau of Statistics, www.dzs.hr.

${ }_{3}^{3}$ Transparency International, https://www.transparency.org/news/feature/corruption perceptions_index_2016\#table (30.08.2017).
} 
Scriptures (in the New Testament), often by outsiders who called those who followed Jesus Christ. ${ }^{4}$ Not once did Jesus call himself or those who followed him Christian. Not one of the gospel writers, Matthew, Mark, Luke or John, nor Paul, who wrote most of the epistles and letters, called followers of Jesus "Christians «. Instead the usual terms used were: brothers and sisters, disciples, believers, followers, the elect, the called, the saints. The name "Christian" (someone who believes in and follows the teachings of Jesus Christ) is and can be only used as a noun and not as an adjective. To develop this thought further in line with this work, it seems incorrect to talk about »a Christian country or nation« as well as »Christian business«.

»Clearly there is a direct link between the profession of faith, the practice of faith, and the plausibility of faith. Practice what you preach and you commend your faith; don't and you contradict it (...) History shows that the very shift in focus from 'Christ' to 'Christianity' is itself a mark of corruption. ${ }^{5}$

Church history is unfortunately loaded with 'marks of corruption' and atrocities done in the 'name of Christ' that have nothing to do with Jesus or his teachings. The link between profession, practice and plausibility of faith was our interest in this work, particularly the contradiction between the profession and practice of faith.

\section{A Theology of Work}

Someone might ask the question »Why a theology of work?« Answers given to this question are a great reminder and motivation for our work.

- »It brings meaning to that portion of a person's life that occupies most of his or her waking hours; it is central rather than peripheral.

- It is essential for putting work in its place, neither one's god (the center of one's meaning) nor simply a curse.

- It is critical for the liberation of the whole people of God for their full-time service in the world since the church is a rhythm of gathering and dispersion.

- It is critical in understanding the mission of the whole people of God since the workplace is where most people »live « and is generally not accessible to professional missionaries.

- Scripture indicates that the deeds of Christian follow them and there will be work in the new heaven and new earth. Since work is not merely a transitory and temporary part of our humanity we need to understand work and our work to be fully human. $\aleph^{6}$

\footnotetext{
${ }^{4}$ Acts 11:26; 26:28; 1 Peter 4:16. ESV

${ }^{5}$ Os GUINNESS, The Call. Finding and Fulfilling the Central Purpose of your Life, Nashville, TN: Word, 1998, 108.

${ }^{6}$ Paul R. STEVENS, »A Contextualized Theology of Work for Asia«, An expanded summary from discussion during the Asian Consultation on Marketplace Theology, Manila, November,
} 
We saw that the majority of Croatians declare themselves as Christians, but at the same time we find a high corruption in the society. The integration of faith (values, virtues, ethics) in the workplace is missing and the gap between God on Sunday and Mammon on Monday is wide. Dorothy Sayers, writer and essayist, made the point,

»In nothing has the church so lost Her hold on reality as in Her failure to understand and respect the secular vocation... but is it astonishing? How can anyone remain interested in a religion that seems to have no concern with nine tenths of his life? «?

Croatia is a high church-attending country in EU. People in Croatia are very serious about the ceremonies (rites), but low on work, free time, friendships ${ }^{8}$. In his pastoral-theological analysis, Josip Baloban reflects on the fact that many members of the Roman Catholic Church reduce their identity and Christianity only to be understood as national, traditional and folklore. Today they become »elective« Christians, meaning they take only certain elements, defined subjectively and individualistically, and neglect holistic creeds, liturgy and the whole of the church teachings. ${ }^{9}$ This creates pastoral problems. Concerning results about the work culture, Josip Baloban asks how is it that after twenty-five years of its independence »Croatia still did not create an ethical culture of work? «10 «Work represents a fundamental aspect of man's existence, « ${ }^{11}$ wrote Pope John Paul II. Paul Stevens points out that one of the difficulties in mobilizing the church towards marketplace ministry is the inadequate understanding regarding a biblical theology of work.

»The two words used by God in his command (Gen 2:15) to Adam to describe work are abad (work) and shamar (take care); interestingly, these words are also used to mean 'service to God' and 'keeping of his commandments' respectively. Thisimplies that no distinction between sacred and secular work is to be made. Likewise the word diakonia is used both for ministry of the word and service at tables in Acts 6:2, 4..12

We started this paper with the assumption that a rightly understood and clearly communicated integration of biblical faith and work can contribute to

28-39, 2007, 7.

7 Dorothy Sayers quoted in Hugh WHELCHEL, How then Should We Work? Rediscovering the Biblical Doctrine of Work, Bloomington, IN: WestBow, 2012, 4.

${ }^{8}$ Josip BALOBAN, Vrednote u Hrvatskoj u europskoj perspektivi. Pastoralno-teološki vid (Values in Croatia in a European Perspective. A Pastoral-Theological View), Bogoslovska smotra, 82 (2012) 4, 955-989, 975; http://hrcak.srce.hr/index.php?show=clanak\&id_clanak_ jezik=141629.

9 Baloban, Vrednote u Hrvatskoj..., 973.

${ }^{10}$ Baloban, Vrednote u Hrvatskoj..., 975.

${ }^{11}$ Laborem Exercens quoted in Lee HARDY, The Fabric of this World. Inquiries into Calling, Career Choice, and the Design of Human Work, Grand Rapids, MI: Eerdmans, 1990, 71.

${ }^{12}$ Stevens, Contextualized Theology..., 7. 
the solution of problems in Croatia. The problematic words in our assumption were »rightly understood « and »clearly communicated.» Although there are many areas of theology where it would be arrogant to presume to have the right understanding, there are equally as many that we can understand rightly. As Mark Twain said: »It ain't those part of the Bible that I can't understand that bother me, it is the parts that I do understand. $\aleph^{13}$ But perhaps the more problematic word is »biblical.« One of the reasons that it is hard to talk about the Bible as the foundation for a theology of work is that, we found in our research, so few people read and understand the Bible.

\section{Survey of Religious Affiliation and Practices}

I conducted three separate surveys in Croatia ${ }^{14}$.The first survey was done among a group of 79 business students with a wide age range (most of these students both study and work: $45 \%$ are employed and $84 \%$ declared themselves as Christians). A second survey interviewed 78 younger, locally active political leaders, in a Leadership class that I taught (67\% employed and $88 \%$ Christian). A third survey involved 72 participants in an EQUIP Leadership training program (83\% employed). The third group was significantly different and particularly relevant for this study as there was a higher average age and more active businessmen, owners of businesses and managers, the majority (76 percent) being between 30-59 years old, the age span for most active marketplace leaders. This group was almost equally divided between Catholics (42\%) and Evangelical-Protestants (43\%) and included priests and nuns, pastors and other workers in Christian ministry. A high number of participants were involved in the business and professional sector (85\%) and (42\%) were also involved in the church and the non-profit sector (mostly as volunteers). The profile of the participants shows that we have an equal representation of males (49\%) and females (51\%). I see this as a highly relevant sample for investigating questions regarding integration of faith and work. Most of the participants identified themselves as Christians, which corresponds to Croatian census data and is consistent with Christianity being the dominant religious affiliation in Croatia.

\footnotetext{
${ }^{13}$ Brainy Quotes at: https://www.brainyquote.com/quotes/quotes/m/marktwain153875.html (30.08.2017).

${ }^{14}$ The surveys were done for the doctoral thesis on the sample of 229 people. Surveys were conducted in 2014 and 2015.
} 


\subsection{Survey Audience Religious Practice}

Following religious affiliation, we asked all three groups about their religious practices like going to church, praying and reading the Bible throughout the year. Those specific answers are significant for our paper. In the following graphs, BS stands for business students, EQUIP for the EQUIP Leadership program participants and PL for the political leaders.

How often did you go to the church in the last year?

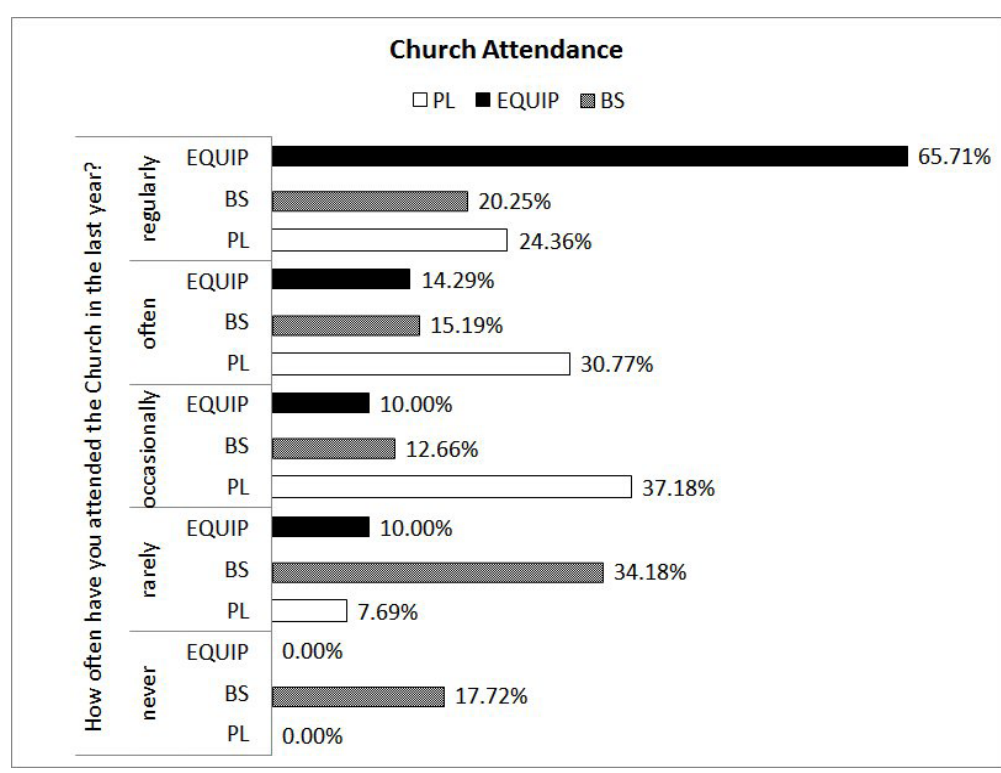

Figure 1. Church Attendance.

We see that most of the Equip participants, $80 \%$, go regularly or often to the church (65.71\% regularly and $14.29 \%$ often). Among the business students, $35.44 \%$ go regularly or often to the church and among political leaders this number is $55.13 \%$. This shows the highest percentage of church attendance among Equip participants and above $50 \%$ among political leaders and somewhat lower among students. Although church attendance is high in Croatia, the problem is that attendance is not correlated with the integration of faith into everyday work, which our research indicated. And this is the main problem! 
How often have you prayed in the last year?

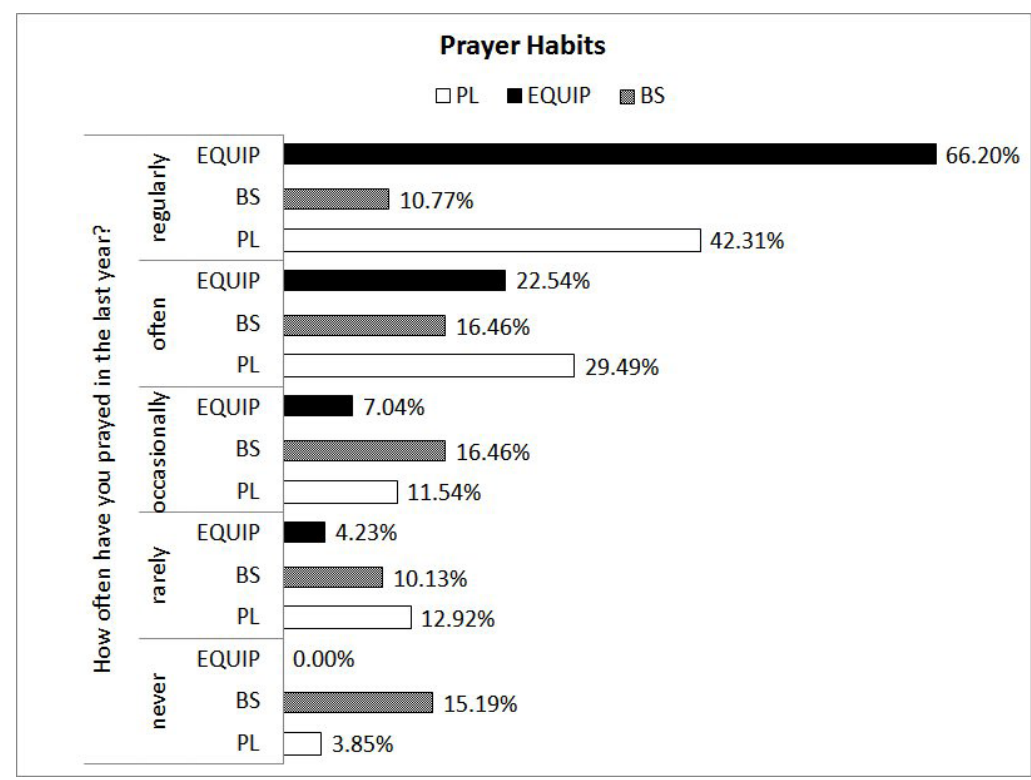

Figure 2. Prayer Habits.

This shows that praying as a spiritual practice of Equip participants (88.74\%) and political leaders $(71.80 \%)$ is high. Business students demonstrate a less frequent prayer life with $27.23 \%$.

How often did you read the Bible in the last year?

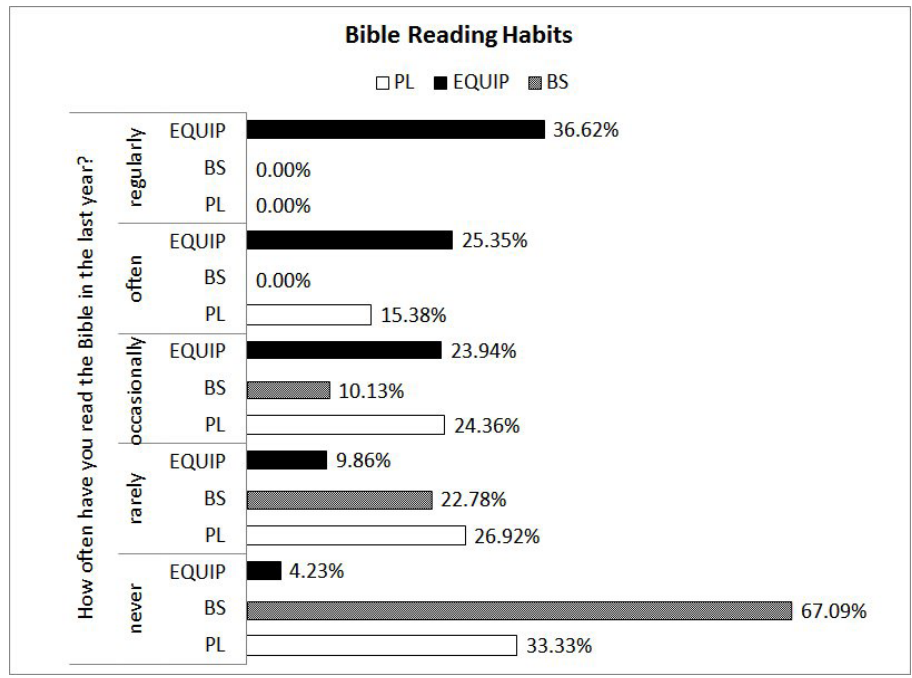

Figure 3. Bible Reading Habits. 
The answers about the Bible reading are very significant for our research. Among EQUIP participants, 36.62\% read the Bible regularly. If we compare only those who answered that they go to church regularly (65.71\%) and pray regularly (66.20\%) with those who read the Bible regularly (36.62\%), we see that this percentage is $30 \%$ lower when it comes to Bible reading. Furthermore, there are $23.94 \%$ of those who answered that they occasionally read the Bible, $9.86 \%$ rarely read the Bible and $4.23 \%$ answered that they never read the Bible during the year.

The two other surveys done among business students and younger political leaders show a different picture concerning Bible reading, which is much lower, and I would add, it reflects more accurately the real situation in Croatia when it comes to biblical (il)literacy. Among political leaders, 33.33\% answered that they never read the Bible and $26.92 \%$ answered that they rarely read the Bible, which makes $60.25 \%$ of the participants who either never or rarely read the Bible in the past year. Only $15.38 \%$ of political leaders answered that they often read the Bible. Not one participant, among political leaders, answered that he or she reads the Bible regularly. Among business students, $67.09 \%$ answered that they never read the Bible and $22.78 \%$ answered that they rarely read the Bible in the past year. This means almost $90 \%$ of students either never or rarely read the Bible. Interestingly not one student answered that he or she read the Bible in the past year, either regularly or often.

Considering that $84 \%$ among business students and $88 \%$ among political leaders described themselves as Christians, these survey results confirm the present biblical illiteracy in Croatia. While our research was limited, it should be researched whether the biblical literacy findings are also reflective of Croatian society in general. From our survey and experience, it would appear to be so, therefore much work needs to be done in promoting and raising the biblical literacy in Croatia. It is hard to understand and talk about the biblical view of work or biblical theology of work when so few people read and understand the Bible and when the Scriptures do not have such importance for most people who describe themselves as Christians. This is one of the important problems, especially for understanding a biblical theology of work. In this paper we will try to »clearly communicate « that the whole Bible has a great deal to say about the importance of honesty, integrity and excellence in our work. ${ }^{15} \gg$ The Bible is an album of casual photographs of laborers... A book by workers, about workers, for workers - that is the Bible. $\aleph^{16}$

\footnotetext{
${ }^{15}$ A broad survey of this could be found in the Theology of Work commentaries that exist to help people explore what the Bible can contribute to ordinary work. The Theology of Work Project (TOW) is the deepest, largest, and most trusted source of biblical, theological, and pastoral material related to work. The Theology of Work Bible Commentary is the only publication ever to cover what the entire Bible says about work; https://www.theologyofwork.org/about/ (30.08.2017).

${ }^{16}$ Paul MINEAR, Work and Vocation in Scripture quoted in R. Paul STEVENS, Work Matters. Lessons from Scripture, Grand Rapids, MI: Eerdmans, 2012, 9.
} 


\section{Understanding the Biblical Drama in Four Acts - a Biblical Framework for Integrated View of Work}

Too often, especially acknowledging a lack of biblical literacy, the biblical story is focused only in two acts: sin/the fall and salvation. Yet it is important that we understand the beginning of the story and the end. In reality, the scriptures describe a four act play or drama of God: Creation, Rebellion (Sin, Fall), Redemption (Salvation), Restoration (Re-Creation). This framework serves as a lens through which we can better understand the whole biblical story. Without looking at this more complete framework, we lose the context and conception of work.

\subsection{First Act: Creation}

The story should start from the beginning with Creation, with Genesis. »In the beginning, God created the heavens and the earth. $\ll^{17}$ Not only does Genesis give us the answer to the fundamental question, »Where did we come from?" but Genesis tells us that there is a God who creates - the God who works. Our God is not a passive, static God, but the God who works. This is not the case in many other religions, particularly in the case of the Greek pantheon or Greek philosophy where gods and philosophers were not working, only slaves served and manually worked. We see on the first page of Genesis that people are created in God's image. Theologians are debating throughout history what it means to be created in God's image (Genesis 1).

»The God said, 'Let us make man in our image, after our likeness and let them have dominion over the fish of the sea and over the birds of the heavens and over livestock and over all the earth and over creeping thing that creeps on the earth.' So God created man in his own image, on the image of God he created him; male and female he created them. And God blessed them. And God said to them, 'Be fruitful and multiply and fill the earth and subdue it and have dominion over the fish of the sea and over the birds of the heavens and over every living thing that moves on the earth.' ${ }^{18}$

One of the characteristics of this image is the capacity to communicate and create, being creative, to rule, to be a steward or manager of the created world and to work. These attributes point to the partnership between God, the Creator, and created humans, confirming the fact that humans are created to work. In their daily work humans are co-workers, partners with God. There is a unity of opinion in Catholic and Protestant theology about this aspect and meaning of human work. Miroslav Volf, in his dissertation where he theologically evaluates Karl Marx's un-

\footnotetext{
${ }^{17}$ Genesis 1:1.

${ }^{18}$ Genesis 1:26-28.
} 
derstanding of work, reflects on the »Cooperator Dei « ${ }^{19}$ concept seen in Genesis 2:5, "When no bush of the field was yet in the land and no small plant of the field had yet sprung up-for the Lord God had not caused it to rain on the land, and there was no man to work the ground.« In Hebrew there is a wordplay going on in those sentences. The word for ground/land is (adama) that sounds like the word for man (Adam). Literally it reads, »There was no Adam for the adama. $\aleph^{20}$ We can see that humans are dependent on God for the rain (and the Creation) in their work. But at the same time, we see the reason »Lord God had not caused to rain« is because there "was no man to work the ground." As if God made himself »dependent» on humans for working the ground!? In another words, God uses human work to continue developing His creation. Creativity is another part of the image of God, a unique attribute given to mankind. »To be made in the image of God means that we are created like God as relational beings and we are made like God in that we work. $\aleph^{21}$ For all those who call themselves Christ followers and believers, this understanding of the God who works and the partnership and role given to mankind to continue God's work on the earth should give a new meaning and inspiration to our daily work. Darrell Cosden talks about the »ontology of work:

»The person is a worker, not as an accident of nature but because God first is a worker and persons are created in his image. Humanity's work, is not identical to God's but is specific to our created existence. Thus, to best understand humanity's work it is essential to look specifically at theological anthropology and not just to God's work. In summary, it is this ontological dimension of work along with its instrumental and relational functions that ultimately gives work its definition and meaningful role in human life. $\aleph^{22}$

\subsubsection{Cultural Mandate}

The word »cultivate « has the same root as the word »culture« and »cult." The word culture comes from latin colo, and means to till the earth, to serve, to worship. Man is created to work, to fill and subdue, keep, protect the earth. To cultivate the soil (using his hands, and feet, developing technology, work) and cultivate the soul (using his mind and heart, giving and creating new names, to think, observe, worship).

Another privilege and »work« given to humans was to name the animals. Usually, explorers who first discovered new mountains or rivers or new chemical elements had this honor to name it themselves as parents have this honor to name their children. This right is given to Adam by God, almost as the finishing touch of God's creation given to mankind to complete the creation. We can

\footnotetext{
${ }^{19}$ Miroslav VOLF, Budućnost rada - rad budućnosti. Pojam rada u Karla Marxa i njegovo teološko vrednovanje, Zagreb, Hrvatsko filozofsko društvo, 1991, 105-106.

${ }^{20}$ I owe this understanding to John DYER, From the Garden to the City. The Redeeming and Corrupting Power of Technology, Grand Rapids, MI: Kregel, 2011, 46.

${ }^{21}$ R. Paul STEVENS, Work Matters: Lessons from Scripture, Grand Rapids, MI: Eerdmans, 2012, 17.

${ }^{22}$ Darrell COSDEN, A Theology of Work, Eugene: Wipf \& Stock, 2004, 17.
} 
see another important element here, namely the first tool used by mankind to cultivate the Garden - language.

"Now out of the ground the Lord God had formed every beast of the field and every bird of the heavens and brought them to the man to see what he would call them. And whatever the man called every living creature, that was its name. (23 $^{23}$

Adam uses language to give different names to animals. Embedded in our language we see our identity and our values. The fact that Adam and Eve are put in the Garden, not a jungle or meadow, is another illustration of the need to cultivate, care for it, to develop. Work has productive and protective aspects: it is created before the fall (rebellion and sin) and our work is not only part of the »cultural mandate, « to take care of the earth, but part of the »covenant mandate, « to belong and honor God.

»Be fruitful and multiply and fill the earth and subdue it and have dominion over the fish of the sea and over the birds of the heavens and over every living thing that moves on the earth. (24 $^{24}$

Work is not created and invented by man, culture is.

"The first phrase, 'be fruitful and multiply,' means to develop the social world: build families, churches, schools, cities, governments, laws. The second phrase, 'subdue the earth,' means to harness the natural world: plant crops, build bridges, design computers, and compose music. This passage is sometimes called the Cultural mandate because it tells us that our original purpose was to create cultures, build civilizations - nothing less. ${ }^{25}$

In the words of Vishal Mangalwady, »God speaks and creates the universe. Man speaks and creates culture that shapes the universe. $\aleph^{26}$ From the beginning, man was created to work and be a culture maker. This gives our work a deeper meaning, value and purpose. The material world matters to God, $\mathrm{He}$ created it and it was good, beautiful. We are given the task and authority (dominion not domination) to be stewards, managers, trustees of His creation.

It is important that we start and understand the beginning of the story, the first act of the four-act play or drama of God. If we start from the Rebellion (fall, sin), we would get the impression that work is cursed as, unfortunately, many people think. We can find the first two parts of the story, two acts of the divine drama (Creation and Rebellion/Fall) explained in the first three chapters of the Scriptures. Most of the rest of the Scripture talks about the work done in a fallen world with the signs of redemption announcing and pointing to the coming of the Redeemer, Messiah (Christ) - Jesus from Nazareth.

\footnotetext{
${ }^{23}$ Genesis 1:31.

${ }^{24}$ Genesis 1:28.

${ }^{25}$ Nancy PEARCEY, Total Truth. Liberating Christianity from Its Cultural Captivity, Wheaton, IL: Crossway, 2005, 47.

${ }^{26}$ Darrow L. MILLER, Marit NEWTON, LifeWork. A Biblical Theology for What you do Every Day, Seattle, WA: YWAM, 2009, 92.
} 


\subsection{Second Act: Rebellion (Sin, Fall)}

The first pages of Creation show us that people were created with a free will; they had a choice and could make free decisions. Man was created with a free will and had a choice and he decided to rebel against his Creator. The fall changed everything. Sin and death entered the story. Sin affected the relationship with God, with each other, with nature and work. Chapter three of Genesis describes the fall. We see in the first pages the difference and consequences which the fall and sin brought to the Creation: shame, blame and nakedness.

The first reaction of Adam and Eve, after their eyes were opened to see for the first time that they are naked, was to sew fig leaves »and made themselves loincloths. ${ }^{27}$ The first reaction to cover our nakedness was to »make« (create) something. John Dyer makes an interesting observation, »Even in their new sinful state, they didn't lose their status as God's image-bearers, and it is almost as if they couldn't help but start creating. ${ }^{28}$ Here the first clothing represents not only physical protection from the nature but a way to hide their nakedness, their sinfulness from God. We read that after the fall, Adam names his wife Eve: »The man called his wife's name Eve, because she was the mother of all living. And the Lord God made for Adam and his wife garments of skins and clothed them. (9 $^{29}$ And we see another act of God's provision making them garments of skin. It shows God's grace, who even after the rebellion and fall takes care of humankind, pointing, together with the words spoken to the serpent, »I will put enmity between you and the woman, and between your offspring and her offspring; he shall bruise your head, and you shall bruise his heel. $^{30}$ - to the coming Redeemer and Savior Jesus. And in our technological age, it is a good reminder that technology (like making the clothing) is not our savior - we saw this tendency from the beginning with making the loincloths from the fig leaves.

\subsubsection{Work and the Covenant with Israel}

God chose and called Israel to enter into a special relationship with him, a covenant relationship. Often a picture of marriage described this kind of close relationship. Israel was the chosen nation to represent, witness and show the one true God to the rest of the surrounding peoples. And this example was not only in the spiritual, religious matters and worship, but in a different behavior in their everyday work and life. This is our calling today. Both the wisdom and prophetic literature is calling us to live and treat our neighbors with shalom and justice. As the Lord is speaking through the prophet Isaiah, »Cease to do evil, learn to do good; seek justice, correct oppression; bring justice to the fatherless,

\footnotetext{
${ }^{27}$ Genesis 3:7.

${ }^{28}$ Dyer, From the Garden to the City..., 70.

${ }^{29}$ Genesis 3:20-21.

${ }^{30}$ Genesis 3:15.
} 
plead the widow's cause. $\varkappa^{31}$ And through the prophet Micah »He has told you, $\mathrm{O}$ man, what is good; and what does the Lord require of you but to do justice, and to love kindness, and to walk humbly with your God. ${ }^{32}$ The psalmist reminds the readers that he who »does not slander with his tongue and does no evil to his neighbor (...) does not take bribes against the innocent (...) shall never be moved. ${ }^{33}$ Israel was supposed to be a living example of God's righteous principles which would benefit them and the peoples around them. But, the story of Israel, as well as showing us a corporate example, provides many individual examples as well. These are the characters that children learn about in their Bible stories but grownups often forget. The Old Testament presents a variety of workers or »business people« if you prefer. I would like to highlight a few, but there are many more who show us by their life example the struggle to live and work by God's principles with excellence. Throughout the Old Testament, we see God at work, fulfilling his purpose and promise given to Abraham, Isaac and Jacob. History is going somewhere and God is in sovereign control.

We find throughout the Old Testament many workers. One whose work is described in detail is Jacob, called the first worker. ${ }^{34}$ We find Jacob serving, almost as a slave, for his two wives, Leah and Rachel, fourteen years. But we read that even such a work, can be done out of love: "So Jacob served seven years for Rachel, and they seemed to him but a few days because of the love he had for her. « $^{35}$ Love transforms all kind of work. His work and breeding plan is described in detail in Genesis 29-32. With his twelve sons, Jacob, later renamed Israel, is the father of the twelve tribes of Israel.

"And God said to him, 'I am God Almighty: be fruitful and multiply. A nation and a company of nations shall come from you, and kings shall come from your own body. The land that I gave to Abraham and Isaac I will give to you, and I will give the land to your offspring after you. ${ }^{36}$

As we read, we see that the family had a lot of deception and dysfunctionality, as Jacob, in a sense »tricks « Laban with the breeding. He is tricked later with Joseph's robe. Wasn't his own father, Isaac, tricked with another robe the clothes of Esau and goatskins, to bless Jacob instead of Esau?

\subsubsection{Joseph the Accidental Executive}

The favorite son, Joseph, is sold into slavery in Egypt. We can follow Joseph's rise from slavery to prison and from prison to the palace - becoming the second in command in Egypt. Joseph's work and position would be like a prime

\footnotetext{
${ }^{31}$ Isaiah 1:17.

${ }^{32}$ Micah 6:8.

${ }^{33}$ Psalm 15:5.

${ }^{34}$ Stevens, Work Matters..., 27.

${ }^{35}$ Genesis 29:20.

${ }^{36}$ Genesis 35:11-12.
} 
minister of a powerful country today, or as a CEO of a global food company. In his great book, $\mathrm{Al}$ Erisman portrayed the life of Joseph in a unique, fresh way. ${ }^{37}$ He looked at Joseph's life with the analytical eye of an experienced businessman who lived most of his life in a challenging, marketplace world. He tells us what we can learn today from Joseph's life being at the bottom of the organization, sold as a slave, put into prison and then later being at the top, in Pharaoh's palace. All of these circumstances brought different temptations. But, sex, power and money have not changed as temptations over the centuries and we can learn a lot for our work today from Joseph and other biblical characters. Erisman, who conducted hundreds of interviews with different marketplace leaders, imagines what kind of questions he would ask Joseph if he had the chance. He shows how the life of Joseph, a biblical character who lived long ago, can illuminate us today and give us practical insights for today's business.

»Whatever our own circumstance, at the top of an organization or at the bottom, the career of Joseph provides a helpful perspective for responding to our vocational call. While he wasn't perfect, he kept his connection with God, worked hard and honorably, regardless of his position, and brought a sense of meaning and purpose to his work. «18

God's grand master plan and His provision for His people is fulfilled with a lot of twists and turns, first, in the story of Joseph, and then in the life of Moses, with a few hundred years between them.

\subsubsection{Moses and the Ten Commandments}

The story of Israel in Egypt and their freeing from slavery through Moses confirm the fulfillment of God's covenant and promise given to Abraham, Isaac and Jacob and their offspring. It also shows that God hears and cares for his people. »Then the Lord said, 'I have surely seen the affliction of my people who are in Egypt and have heard their cry because of their taskmasters. ${ }^{39}$ What do we know about Moses? We know that he was an Israelite, saved as a baby from the water, raised like a prince by Pharaoh's daughter, attended the best schools in Egypt and was groomed for a leadership position in Egypt for the first forty years. We know that he murdered an Egyptian and ran for his life into the desert where he spent another forty years working as a shepherd. This Moses is called by God and sent back to Egypt to free God's people. This is an important story in Israel's history and the history of the world. I will concentrate on one particular story from Moses life, receiving the Law, the Ten Commandments, as it has significance for this work.

\footnotetext{
${ }^{37}$ Albert M. ERISMAN, The Accidental Executive: Lessons on Business, Faith, and Calling from the Life of Joseph, Peabody, MA: Hendrickson, 2015.

${ }^{38}$ Erisman, The Accidental Executive..., 178.

${ }^{39}$ Exodus 3:7.
} 
The Law, the Ten Commandments, was written down. At this time in a predominantly oral culture (aprox. around 1444 B.C.) writing was a new concept of communication, a new technology. The tablets were written by God and given to Moses.

»Then Moses turned and went down from the mountain with the two tablets of the testimony in his hand, tablets that were written on both sides; on the front and on the back they were written. The tablets were the work of God, and the writing was the writing of God, engraved on the tablet. « ${ }^{40}$

For the first time in an oral culture, knowledge, that was, until then, only stored in the human mind, was available outside and extended the mind of one person. It became available to all the people who could read, regardless of their age. This was a significant cultural change. Transition of leadership from Moses to Joshua is one good illustration of this change. Age was not the barrier anymore - anyone who could read could access knowledge. So the younger Joshua could lead after the old Moses because Moses wrote all the things he learned and experienced with God, including the requirements of the God-given law.

There are different interpretations of the meaning of the Ten Commandments. The first two commandments are very different and unique in comparison with other surrounding nations and cultures in the ancient time with similar ethical requirements. Regardless if we read the prologue (I'm the Lord your God, who brought you out of the land of Egypt, out of the house of slavery.) as the first commandment (as some interpreters do) ${ }^{41}$ or if we first start with, You shall have no other gods before me - the first commandment is unique and exclusive and separated Israel from all the surrounding cultures with its direct focus on Yahweh, the only true God, the Creator who delivered them from Egypt. Israel was called to be a monotheistic culture. From this first commandment, rightly understood, putting God at the exclusive and central place, all the rest are following:

1. »I'm the Lord your God, who brought you out of the land of Egypt, out of the house of slavery. You shall have no other gods before me.

2. You shall not make for yourself a carved image, or any likeness of anything that is in heaven above, or that is on the earth beneath, or that is in the water under the earth. You shall not bow down to them or serve them, for I the Lord your God am a jealous God. $\aleph^{42}$

The second commandment follows in the same personal way (first person), I the Lord your God am a jealous God. In the second commandment, God strictly forbids making any carved image. As Neil Postman said,

\footnotetext{
${ }^{40}$ Exodus 32:15-16.

${ }^{41}$ David Gill in his book Doing Right introduces and interacts with different scholars (Maillot, Lochman, Rabi Chouraqui, Feuer, Hertz, and others) who wrote about the Ten Commandments (David W. GILL, Doing Right. Practicing Ethical Principles, Downers Grove, IL: IVP, 2004).

${ }^{42}$ Exodus 20:3-4.
} 
»It is a strange injunction to include as part of an ethical system unless its author assumed a connection between forms of human communication and the quality of a culture. $\aleph^{43}$

In the second commandment, God is telling Israel, and us, that the images, tools, and forms matter to him. This reflection on the second commandment is important for the Croatian context because Croatia is predominantly a Roman Catholic country. And, sadly enough, the Roman Catholic Church teaches (every child learns it from the earliest days in their religious education) the shorter version of the Ten Commandments without the second commandment, the second commandment is missing (in making up the number 10, the tenth commandment is divided into two parts although both ninth and tenth commandments in this interpretation are about coveting).

The question that comes to mind is, „Can people, in their worship and prayers, with so many statues in churches, pictures, images and forms, focus on God as the exclusive and only true center of our worship? « As Postman asks, »Is there an assumed 'connection between forms of human communication and the quality of a culture?'" Not understanding (or purposely ignoring it) the importance of the second commandment might have, and has, (negative) consequences for »the quality of a culture.«

»Therefore, God decreed that the people of Israel were to approach him exclusively through the names, metaphors, and ideas found in the permanent, authoritative words of Scripture. The medium was the message. $\ll^{44}$

This topic is discussed in depth by many other authors like Neil Postman, David Gill and others, and is not the focus of this work. I wanted to point out the importance and significance of the written word (among others the written words of God on the tables given to Moses) at a historical time like Exodus.

The fourth commandment is more related to the Sabbath-work rhythm. It is, in a sense, a double commandment; on one hand, it said that we should work six days and, yet, we are commanded to keep the seventh day as a Sabbath. Man created in the image of God has the right to work - it is part of his image and we saw that we should think about work not only as instrumental and relational but ontological. We find two Sabbath commandments in Exodus 20:8-11 and Deuteronomy 5:12-15. One is rooted in the creation and the other in the exodus from Egypt. Sabbath gives boundaries to our work. It includes everyone. Even the animals are provided rest. Sabbath, in the creation story, is given and observed by God before the fall and God declared it holy. An interesting observation by David Gill is that Jesus is resurrected, not on the Sabbath, the religious day (Saturday), but on the first working day of the regular week (then

\footnotetext{
${ }^{43}$ Neil POSTMAN, Amusing Ourselves to Death. Public Discourse in the Age of Show Business, New York, NY: Penguin, 1986, 9.

${ }^{44}$ Dyer, From the Garden..., 114.
} 
Sunday). Because of Jesus' resurrection on Sunday, Christians observe Sunday as the Lord's Day and think of it as the »new Sabbath.«»The resurrected Jesus shows up in our work week - not just in our religious times and places. ${ }^{45}$ But still, the work is done in a fallen world, corrupted by sin, which brings us to next act of the biblical drama: Redemption and Salvation.

\subsection{Third Act: Redemption (Salvation, Cross and Resurrection)}

The central event of History or »the Center,« as E. Stanley Jones would say, is, $»$ The Word became Flesh. $\aleph^{46}$

»This verse (the Word became flesh) - is the Great Divide. In all other religions it is Word became word - a philosophy, a moralism, a system, a technique, but for all time and all people everywhere, 'the Word became flesh' - the 'Idea became Fact'. ${ }^{47}$

The apostle John is witness to this fact: »And the Word became flesh and dwelt among us, and we have seen his glory, glory as of the only Son from the Father, full of grace and truth. $\aleph^{48}$ As Douglas Webster said: »At the birth of the Son of God there was brightness at midnight; at the death of the Son of God there was darkness at noon. ${ }^{49}$

We saw how the Ten Commandments start, with God revealing himself as the Lord who brought Israel out of Egypt: »I'm the Lord your God, who brought you out of the land of Egypt, out of the house of slavery, « and we know that this event was the beginning of the exodus, an event that started with the marking of their doorsteps with the blood of a lamb in the night when the Lord passed over those houses that were marked! The first exodus was remembered every year. The Israelites were to commemorate this day for the generations to come. Now, it is Passover time again. We have the cross on which Jesus is hanging, at the precise time when the Passover lambs were being slaughtered. John the Baptist said of Jesus, »Behold, the Lamb of God, who takes away the sin of the world. $\aleph^{50}$ The apostle Paul wrote that »for Christ, our Passover lamb has been sacrificed. $\aleph^{51}$ We have a new exodus and a new covenant, this time with the blood of the Lamb of God, Jesus. The cross and the resurrection of Jesus the Messiah is the central event in the History - it is »the Center! « ${ }^{52}$ The cross and

\footnotetext{
${ }^{45}$ Gill, Doing Right..., 150.

${ }^{46}$ Stanley E. JONES, The Word Became Flesh, Nashville, TN: Abingdon, 2006, 9.

${ }^{47}$ Jones, Word Became Flesh..., 9.

${ }^{48}$ John 1:14.

${ }^{49}$ John R. W. STOTT, The Cross of Christ. $20^{\text {th }}$ Anniversary ed, Downers Grove, IL: IVP, 2006, 81.

${ }^{50}$ John 1:29.

${ }^{51} 1$ Corinthians 5:7.

${ }^{52}$ The centrality of Jesus as Christus Victor, a theme found in the early church, is possibly the answer, in our postmodern world, to the search for the »unifying principle « in the universe (Jesus as the »cosmic redeemer«), and the problem of »personal and corporate evil« postmodernism
} 
the resurrection bring us reconciliation and salvation. Jesus through his death on the cross redeems and reconciles our relationship with God and this affects and redeems all other relationships that were broken after the fall - the relationship with each other, with nature, with our work and culture. We are still living in the fallen world, marred by sin, but the Kingdom of God has come, a paradox in which we are called to live and work - it is here and yet to come. Jesus' resurrection and the scars on the resurrected body give us hope that one day our bodies will be resurrected and that things we do here in Jesus' name have eternal value, as his scars prove.

\subsubsection{Jesus as Tekton}

Jesus' life, death and resurrection are the main events that most of the scriptures are leading to and overshadows everything else. And even here we see the emphasis and expansion of the concept of work. It is easily forgotten that Jesus, the incarnate Word, was born into an entrepreneurial family. Joseph worked as a carpenter, more likely like a builder, tekton, and Jesus, most likely as any boy would in this time, helped in the family business. We do not have any precise information regarding Jesus' life between the age of 12 and 30, but most likely, it was spent working in the marketplace of his time. It is hard to imagine Jesus doing a bad or sloppy job either building a chair, a yoke or a house. In addition, many of the 12 apostles came from the business world: a few of them were small entrepreneurs, four of them came from family fishing businesses, Matthew was a tax collector, we know that Judas held the money, maybe he knew something about finances. Interestingly, not one was a priest or theologian. In Jewish tradition, even the rabbi would need to learn a trade, as we later see with Paul being a tentmaker. This shows the importance of work in the Jewish culture. Jesus is using many parables and illustrations from the ordinary, everyday life and work. »Of Jesus' 132 public appearances in the New Testament, 122 were in the marketplace; of the fifty-two parables that Jesus told, forty-five had a workplace context. . $^{53}$ Before his three years of ministry, Jesus was working most of his life in the marketplace of his region.

»The Word became flesh" as the center or the central verse, shows that the prevailing »dualism, « where spiritual, sacred is more important and good and the material, secular is second class and bad, is wrong! Jesus Christ came into the flesh, worked as a builder (carpenter) most of his life, died on the cross and was resurrected in the new body showing us that our future is material as well as spiritual. His scars are proof of that.

faces beside saying that we are dealing with a »tragic optimism. « Those thoughts are greatly described in Robert E. WEBBER, Ancient-Future Faith. Rethinking Evangelicalism for a Postmodern World, Grand Rapids, MI: Baker, 2003.

${ }^{53}$ Stevens, Work Matters..., 134. 
His disciples were carrying his message. Throughout the New Testament, we find a strong reference to work. Starting with Acts: »of forty divine interventions recorded in that book, thirty-nine took place in the marketplace or public square! $\aleph^{54}$

The two-act biblical drama ends with the salvation. But salvation is only the first step not the last one. What we often miss is the motivation and inspiration that the right understanding of the end of the story brings. If our eschatology points to »going to Heaven" and our dualism declares things of this earth as evil, this would influence our understanding of present work. It can make us passive. But we read about the "New Heaven and new Earth." What is this New Earth? We will end with the fourth act of the biblical drama: Restoration, Re-creation, Renewal.

\subsection{Fourth Act: Restoration (Re-Creation, Renewal)}

Our eschatology determines our (business) ethics. If we look at work through the lens of the »new creation « it gives us an eternal view and deepens our understanding of work even more:

»This is not to say that these theologians have ignored protology or its importance in understanding work. Rather, their eschatologically orientation means that from protology, work is perceived as teleologically directed and oriented forward toward the future new creation rather than backward toward their restoration of the initial creation. It would not be inappropriate to claim therefore, that with this »new creation « orientation, work becomes a type of eschatological mandate rather than simply a creation mandate. Herein lies a significant shift in ethics. $\aleph^{55}$

Or putting it in a more practical picture, we start with the picture of a party »it seems that the whole Biblical revelation points to this: God's first thought was the marriage supper of the Lamb, the final rendezvous of God, creation, and humankind. And to get there, he made the world, made God-imaging humankind, and even sent his Son to redeem everything. ${ }^{56}$

We started our story in the garden, but now we end the story with the city. We read in Revelation about the city, New Jerusalem, coming down to Earth:

»Then I saw a new heaven and a new earth, for the first heaven and the first earth had passed away, and the sea was no more. And I saw the holy city, the new Jerusalem, coming down out of heaven from God, prepared as a bride adorned for her husband. And I heard a loud voice from the throne saying, 'Behold, the dwelling place of God is with man. He will dwell with them, and they will be his people, and God himself will be with them as their God.' ${ }^{57}$

\footnotetext{
${ }^{54}$ Stevens, Work Matters..., 134.

${ }^{55}$ Cosden, Theology of Work..., 46.

${ }^{56}$ Stevens, Work Matters..., 5.

${ }^{57}$ Revelation 21:1-3.
} 
Have we not, throughout the centuries, prayed the Lords prayer: »Thy Kingdom COME, thy will be done on Earth as it is in Heaven.« Did not Jesus, with his resurrected body and scars from the cross, give us an example and hope that one day we, too, will have new, transformed bodies and that we will join the multitudes of saints who will enter the New Jerusalem on the new Earth and be with our God? R. H. Gundry has argued persuasively that

»In Revelation the saints' dwelling place is the new earth. It is 'quite clear that the Book of Revelation promises eternal life on the new earth..., not ethereal life in the new heaven.... Theologically, it makes little sense to postulate a non-earthly eschatological existence while believing in the resurrection of the body.«1

As we read in Romans 8 the whole creation was groaning and waiting for the revealing of the sons of God,

»For I consider that the suffering of this present time are not worth comparing with the glory that is to be revealed to us. For the creation waits with eager longing for the revelation of the sons of God. For the creation was subjected to futility, not willingly, but because of him who subjected it, in hope, that the creation itself will be set free from its bondage to corruption and obtain the freedom of the glory of children of God. ${ }^{59}$

As Paul Marshall said: »Our destiny is an earthly one: a new earth, an earth redeemed and transfigured. An earth reunited with heaven, but an earth, nevertheless. ${ }^{60}$ Our eschatology influences our (business) ethics. Knowing the end should help us to live our part in the story of God now.

\section{Is our Work in Vain}

Our motivation depends on what we think about work. Will it last? Is it spiritual enough? Is it in vain? Paul reassures us that our work is not in vain, »Therefore, my beloved brothers, be steadfast, immovable, always abounding in the work of the Lord, knowing that in the Lord your labor is not in vain. (61 $^{61} \mathrm{~N}$. T. Wright reminds us that this verse comes at the end of one of the »longest and densest chapters « that Paul wrote in any of his letters

»discussing the future resurrection of the body in great and complex detail...

The point of the resurrection, as Paul has been arguing throughout the letter, is that the present bodily life is not valueless just because it will die. God will raise it to new life. What you do with your body in the present matters because God has a great future in store for it. ${ }^{62}$

\footnotetext{
${ }^{58}$ Miroslav VOLF, Work in the Spirit. Toward a Theology of Work, Eugene, OR: Wipf and Stock, 1991, 94-95.

${ }^{59}$ Romans 8:18-21.

${ }^{60}$ Paul Marshall quoted in Hugh WHELCHEL, How then Should We Work? Rediscovering the Biblical Doctrine of Work, Bloomington, IN: WestBow, 2012, 27.

${ }^{61} 1$ Corinthians 15:58.

${ }^{62}$ N. T. WRIGHT, Surprised by Hope. Rethinking Heaven, the Resurrection, and the Mission of the Church, New York, NY: Harper One, 2008, 192.
} 
This earthly body, although it will die is the means to an eternal weight of glory beyond all comparison. This is an amazing concept yet not easy to understand, but very often repeated in the New Testament. What we do in this present life, in this earthly body has eternal consequences. This biblical and eschatological truth, rightly understood, affects how we live and work now.

\subsection{Salt and Light}

In the Old Testament, the Holy Spirit was given only to some people, prophets, kings, and including Bezalel a craftsman. In the New Testament, the Holy Spirit is given to everyone who repents and believes in the resurrected Jesus. We read in Romans 12 that the Holy Spirit is giving us different spiritual gifts, many of them useful, not only at our church gatherings or only for »spiritual « activities, but in our everyday work like leadership, teaching, serving, generosity, and acts of mercy. We are called to be a priesthood of all believers as the apostle Peter is saying,

»but you are a chosen race, a royal priesthood, a holy nation, a people for his own possession, that you may proclaim the excellencies of him who called you out of darkness into his marvelous light. « ${ }^{63}$

We can see the similarity with the role Israel had in the Old Testament. God entered with us (his chosen Ecclesia, the Body of Christ) in a new covenantal relationship, this time through the blood of Jesus - we are called the Bride of Jesus. We are called to be the salt and light of the world. Where is salt needed more than in our workplace and our everyday lives? Where is light needed more than in the darkness of society and the culture around us? We are called to live and work with faith, love and hope. And as we live and work, as we go, we are called to make disciples, to teach all nations all that Jesus has commanded, and to be a faithful presence in all our spheres of influence (including marketplace). And Jesus promises to be with us all the time, to the end of the age/time. ${ }^{64}$

\subsection{Paul as a Tentmaker}

The apostle Paul worked as a tentmaker. When working with Priscilla and Aquila, he urges the disciples to work.

»But we urge you, brothers to do this more and more and to aspire to live quietly, and to mind your own affairs, and to work with your hands, as we instructed you, so that you may walk properly before outsiders and be dependent on no one. ${ }^{65}$

\footnotetext{
${ }^{63} 1$ Peter 2:9.

${ }^{64}$ Matthew 28:18-20. Theses verses are often called Great Commission.

${ }^{65} 1$ Thessalonians 4:11.
} 
One of the reasons to work is not to be dependent on others, especially on those outside the faith. By working with their own hands, Paul and those accompanying him wanted to give a good example and not to be a burden to anyone.

»Now we command you, brothers, in the name of our Lord Jesus Christ, that you keep away from any brother who is walking in idleness and not in accord with the tradition that you received from us. For you yourselves know how you ought to imitate us, because we were not idle when we were with you nor did we eat anyone's bread without paying for it, but with toil and labor we worked night and day that we might not be a burden to any of you. It was not because we do not have that right, but to give you in ourselves an example to imitate. For even when we were with you, we would give you this command: if anyone is not willing to work, let him not eat. ${ }^{66}$

And Paul is reminding the Ephesians and all of us that, by working, we not only take care of our own needs, but we also help those in need around us. »Let the thief no longer steal, but rather let him labor, doing honest work with his own hands, so that he may have something to share with anyone in need. ${ }^{67}$ Paul is encouraging believers in Colossae to work in the name of the Lord Jesus, and when talking to slaves, he is reminding them that they are serving the Lord Jesus Christ.

»And whatever you do, in word or deed, do everything in the name of the Lord Jesus, giving thanks to God the Father through him (...) Whatever you do, work heartily, as for the Lord and not for the men, (...) You are serving the Lord Christ! ${ }^{68}$

We could ask ourselves today are we working heartily as working for Jesus in everything we do? The story that started in the Garden is finishing in the City. In this (eschatological) story our work might have eternal value. Knowing the end should help us to live our part in the story of God now. Our role did not change. We are still called to be stewards of God's creation. We are called to be His cocreators, co-workers, knowing that because of the cross and resurrection, we are reconciled with God and have the ministry of reconciliation (2 Cor 5),

»All this is from God, who through Christ reconciled us to himself and gave us the ministry of reconciliation; that is, in Christ God was reconciling the world to himself, not counting their trespasses against them, and entrusting to us the message of reconciliation. Therefore, we are ambassadors for Christ, God making his appeal through us. We implore you on behalf of Christ, be reconciled to God. « ${ }^{69}$

\footnotetext{
${ }^{66} 2$ Thessalonians 3:6-10.

${ }^{67}$ Ephesians 4:28.

${ }^{68}$ Colossians 3:17, 23.

${ }^{69} 2$ Corinthians 5:18-6:1.
} 


\section{Conclusion}

We started this paper with the assumption that a rightly understood and clearly communicated integration of biblical faith and work can contribute to the solution of problems in Croatia. The problematic words in our assumption were »rightly understood « and »clearly communicated." One of the reasons these are problems is that it is hard to talk about the Bible as the foundation for a theology of work when, as we saw in our research, so few people read and understand the Bible. Our hope is that understanding the biblical drama in four acts (Creation, Rebellion, Redemption and Restoration) can serve as a framework for integrated view of work. This framework serves as a lens through which we can better understand the whole biblical story.

We saw a gap between a declared Christian faith and the lack of visible works which should flow out from such a belief. If Croatians (who call themselves Christians, meaning those who are followers of Christ) connected Sunday and Monday, living out their (spiritual, moral, ethical) values, a workplace theology that is communicated through their work, would this contribute to a positive (ethical) change in a culture? Could the integration of faith and work redeem and transform the motivation and meaning of work?

Our motivation depends on what we think about work. Will it last? Is it spiritual enough? Is it in vain? Paul reassures us that our work is not in vain, »Therefore, my beloved brothers, be steadfast, immovable, always abounding in the work of the Lord, knowing that in the Lord your labor is not in vain. $\aleph^{70}$ What we do -

»by painting, preaching, singing, sewing, praying, teaching, building hospitals, digging wells, campaigning for justice, writing poems, caring for the needy, loving your neighbor as yourself - will last into God's future. «11

All this work »we may call building for God's kingdom. «" All good work is Kingdom work. Only by rightly understanding this truth can we hope that the integration of our faith and work can redeem and transform our motivation and attitude toward work in Croatia. And this is worth hoping for. The words of former Prime Minister of Netherlands (1901-1905) Abraham Kuyper well illustrate the point: »There is not a square inch in the whole domain of our human existence over which Christ, who is Sovereign over all, does not cry, Mine! « $^{73}$ We cannot be »Christians« only on Sunday - Monday matters!

\footnotetext{
${ }^{70} 1$ Corinthians 15:58.

${ }^{71}$ Wright, Surprised by Hope..., 193.

${ }^{72}$ Wright, Surprised by Hope..., 193.

${ }^{73}$ Sphere Sovereignty cited in James D. BRATT (ed.), Abraham Kuyper. A Centennial Reader, Grand Rapids, MI: Eerdmans, 1998, 488.
} 


\section{Dražen Glavaš*}

Jesmo li mi »kršćani« samo nedjeljom? Što je s ponedjeljkom? Biblijska drama u četiri čina kao model za razumijevanje integriranog pogleda na rad

\section{Sažetak}

Hrvatska je izrazito kršćanska zemlja (više od 91 \% građana se izjasnilo kao kršćani), ali to, nažalost, ne znači da je istodobno zemlja visoke etičnosti. U stvarnosti se Hrvatska bori na mnogo etičkih bojišta. Ovaj rad započinje s pretpostavkom da ispravno shvaćena i jasno komunicirana integracija biblijske vjere i rada može doprinijeti rješenju problema u Hrvatskoj. Istraživanja su potvrdila da malo ljudi čita i razumije Bibliju. Kada Sveto pismo nema toliku važnost, za većinu ljudi koji se izjašnjavaju kao kršćani, teško je govoriti o biblijskom pogledu na rad i razumjeti biblijsku teologiju rada. Predlaže se novi model za razumijevanje integriranoga pogleda na rad kojim se može bolje razumjeti cjelinu biblijske priče. Bez takvoga potpunijeg modela gubi se kontekst i shvaćanje rada.

Ključne riječi: integracija vjere i rada, teologija rada, poslovna etika, korupcija, etička kultura u Hrvatskoj, čitanje Biblije, biblijska drama u četiri čina, rad za Kraljevstvo.

\footnotetext{
* Dr. sc. Dražen Glavaš, viši predavač poslovne etike i liderstva na Sveučilištu Vern' i poslovni trener s ET!Kom; S. Vojnovića 42, Gajec, HR-10000 Zagreb, Croatia; E-mail: drazen.glavas@ etik.hr.
} 